Revue

Revue de l'histoire des religions

del'histoire

des religions

1| 2017

Varia

\title{
Matthew 5:22 : The Insult "Fool" and the Interpretation of the Law in Christian and Rabbinic Sources
}

Matthieu 5:22: L'insulte "insensé » et l'interprétation de la Loi dans les sources chrétiennes et rabbiniques

Michal Bar-Asher Siegal

\section{OpenEdition}

\section{Journals}

Electronic version

URL: http://journals.openedition.org/rhr/8651

DOI: ERREUR PDO dans /localdata/www-bin/Core/Core/Db/Db.class.php L.34 : SQLSTATE[HYOOO]

[2006] MySQL server has gone away

ISSN: 2105-2573

\section{Publisher}

Armand Colin

Printed version

Date of publication: 1 March 2017

Number of pages: $5-23$

ISBN: 978-2-200-93125-4

ISSN: 0035-1423

Electronic reference

Michal Bar-Asher Siegal, "Matthew 5:22: The Insult "Fool" and the Interpretation of the Law in Christian and Rabbinic Sources", Revue de l'histoire des religions [Online], 1 | 2017, Online since 01 March 2019, connection on 07 January 2021. URL: http://journals.openedition.org/rhr/8651 ; DOI: https://doi.org/10.4000/rhr.8651 


\section{Matthew 5:22 : The Insult "Fool" and the Interpretation of the Law in Christian and Rabbinic Sources}

The use of sources outside the New Testament, from the writings of Qumran to those of the rabbis, can help clarify the semantic and theological field in which Matthew 5:22 should be understood. This article claims that the correct interpretation of the Law stood at the center of arguments between different groups in the late Second Temple period and later; that the insults raka "empty" and mōre "fool" are connected to this polemical environment; and that it is within this setting that the Sermon on the Mount should be understood.

\section{Matthieu 5 : 22 : L'insulte « insensé » et l'interprétation de la Loi dans les sources chrétiennes et rabbiniques}

Le recours à des sources extérieures au Nouveau Testament, depuis les manuscrits de Qumrân jusqu'à la littérature rabbinique, peut permettre de clarifier la nature du champ sémantique et théologique au sein duquel le verset 5 : 22 de l'Évangile selon Matthieu doit être compris. Cet article affirme que l'interprétation correcte de la Loi (mosaïque) figurait au coeur de disputes entre différents groupes juifs de la fin de la période du Second Temple et au-delà ; que les insultes raka ("vide») et mōre ("insensé ») sont liées à ces polémiques, et que c'est dans ce contexte que le Sermon sur la Montagne doit être replacé.

* I am grateful to the following people with whom I discussed parts of this paper : Laura Nasrallah, Nathan Eubank and Vered Noam. I would especially like to thank Katell Berthelot, Elitzur Bar-Asher Siegal, Tobias Nicklas and the participants of the "Law and Lawlessness in Early Judaism and Christianity," the first Lautenschläger colloquium, Oxford University (August 2015), who read drafts of this paper and offered many helpful comments. In quoting from rabbinic sources, I use the MS versions as copied in the Historical Dictionary website, Ma'agarim, of the Academy of the Hebrew Language. 
In Matthew's Sermon on the Mount, Jesus famously announces that he has not come "to abolish the law or the prophets," but rather "to fulfill" the law. According to this literary depiction, his contemporaries, the scribes and Pharisees, were not doing it right. Jesus, therefore, asks that his listeners exceed their righteousness. ${ }^{1}$ He provides several examples to illustrate his point, calling for a "shift from a casuistic criminal law to a moral rule." 2 In Jesus' list, the sin of adultery begins with a lustful look, and he urges his followers to avoid oaths. The first example, however, addresses insults to others (Matt 5:22): ${ }^{3}$

You have heard that it was said to the men of old, "You shall not murder"; and "whoever murders shall be liable to judgment." ${ }^{4}$ But I say to you, everyone who is angry with his brother or sister ${ }^{5}$ is liable

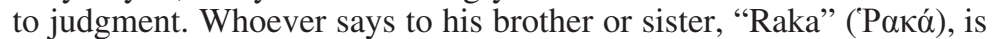

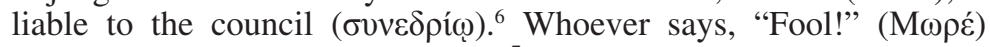
is liable to the hell of fire $(\gamma \varepsilon \dot{\varepsilon} \varepsilon v \alpha v){ }^{7}$

Here, and in the context of the larger section (5:21-26), Jesus discusses anger and, especially between brothers, he "demands an end to anger and hateful speech." ${ }^{8}$ In this passage, insults to one's

1. In the various ways to treat the purpose of The Sermon on the Mount in relation to the Pharisaic laws see Herbert W. Basser, The Gospel of Matthew and Judaic Traditions : A Relevance-Based Commentary (Boston : Brill, 2015), 113-19.

2. Hans Dieter Betz, The Sermon on the Mount : A Commentary on the Sermon on the Mount, Including the Sermon on the Plain (Matthew 5:3-7:27 and Luke 6:20-49) (ed. Adela Yarbro Collins ; Minneapolis : Fortress Press, 1995), 219.

3. The source critical examination of the antitheses (Matt 5:21-48) reveals a few different units. Scholars have focused on the different sections of verse 22. On this see Ulrich Luz, Matthew : A Commentary (Hermeneia ; 3 vols. ; Minneapolis : Fortress Press, 2001), $1: 233-34$.

4. Exod 20:12; Deut 5:16. See also Exod 21:12; Lev $24: 17$.

5. Some MSS read "without cause." I agree with Betz's assessment that this is a "secondary ethical interpretation" (Betz, Sermon on the Mount, 219). Following Nollan and France, I have adopted the translation of $\dot{\alpha} \delta \varepsilon \lambda \varphi \tilde{\omega}$ as "brother or sister" to reflect a generic rather than gender-specific reference.

6. On the translation of this word as "the Sanhedrin," see survey and references in Robert A. Guelich, "Mt 5:22 : Its Meaning and Integrity," ZNW 64 (1973), 42-44.

7. Since the bibliography on this unit is extremely vast, I have chosen to focus on studies that are important for my argument. For a survey of recent literature see for example John Nolland, The Gospel of Matthew : A Commentary on the Greek Text (Grand Rapids, Mich. : Wm. B. Eerdmans, 2005), 227-28.

8. W. D. Davies, A Critical and Exegetical Commentary on the Gospel According to Saint Matthew, Volume 1: Matthew 1-7 (3 vols.; Edinburgh : T\&T Clark, 1988-1997), 511. This phrasing, as opposed to many Western 
brother or sister ${ }^{9}$ are deemed equal to murder and deserving of court procedures and hell. ${ }^{10}$ Jesus here "appears to accept the legal focus $[\ldots]$ only to parody and discredit it as an adequate framework for appreciating the thrust of the commandment." 11 In a parallel literary structure, the Aramaic word (reqa) and the Greek

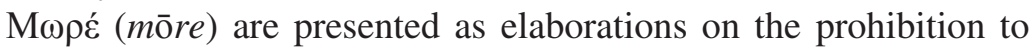
become angry with another person. ${ }^{12}$

Scholars have long debated the exact nature of the offense deemed so severe by Jesus. Even if read as an ethical demand rather than an actual legal prohibition, ${ }^{13}$ why are these insults considered so reprehensible as to be equated to murder? The specific slurs used as examples naturally stand at the heart of the discussion.

The appearance of these two insults in the text of Matthew in their original language (this is the sole appearance of raka in the NT) points to an audience that is comfortable cursing in different languages, including Aramaic and Greek. ${ }^{14}$ The difference between raka and the Aramaic reqa, could stem from the Syriac raqa.${ }^{15}$ Puzzlingly, the two terms seem parallel in their meaning, and scholars have tried to discern the exact difference between the

writers since Irenaeus, who based their reading on the addition "without cause", limiting the extent of Jesus's words to unjustified anger. See, for example, Luz, Matthew, 238.

9. On the meaning of "brother," $\alpha \delta \varepsilon \lambda \varphi \tilde{\omega}$, in this context, whether "Christian brother" or simply "neighbor," see references in Davies, Critical and Exegetical Commentary, 512-13. R. T. France, The Gospel of Matthew (Grand Rapids, Mich. : Wm. B. Eerdmans, 2007), 200n80, notes that the community sense of this term is "more characteristic of Matthew than of the other gospels."

10. On the relationship between this unit in Matt and what we find in the Dead Sea Scrolls, see John Kampen, "A Reexamination of the Relationship between Matthew 5:21-48 and the Dead Sea Scrolls," Society of Biblical Literature: Seminar Papers 29 (1990) : 34-59. On the move from an earthly punishment to that of hell see Luz, Matthew, 236.

11. Nolland, Gospel of Matthew, 230.

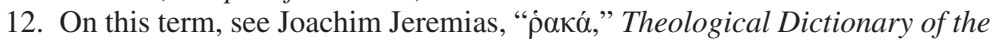
New Testament (ed. G. Kittel and G. Friedrich ; trans. G. W. Bromiley ; 10 vols. ; Grand Rapids, Mich. : Wm. B. Eerdmans, 1964-1976), 6 : 973-76.

13. See Betz, Sermon on the Mount, 221.

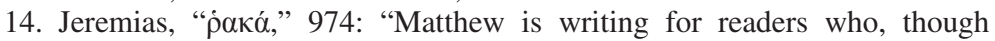
they speak Greek, can understand an oriental term of abuse without further ado" (emphasis mine). This may have a bearing on the original language of the gospel ; see Betz, Sermon on the Mount, 220-21 and n173.

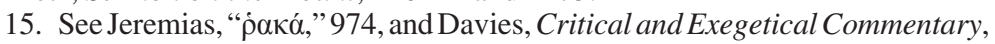
513n6. See below p. 16ff. for further discussion. 
two. ${ }^{16}$ Jonathan Watt has summarized recent views, which have moved away from a search for finite differences between these two terms, in favor of his suggestion that this doubling stems from the kind of "code-switching" common to bilingual communities: ${ }^{17}$

Code-switching between the region's native language (Aramaic), its historic and sometimes current language of religious discourse (Hebrew - which may have been the medium when a young Jesus impressed his seniors at the temple, Luke 2:46-47), and even its tertiary language of wider communication (Greek), would have been comfortable communicative behavior. Multilingual speakers draw effortlessly from their repertoire, as Jesus and the Gospel writer seem to have done.

Interestingly, the insult "fool" is used in the New Testament, for example, in the mouth of Jesus himself, when he calls the Pharisees

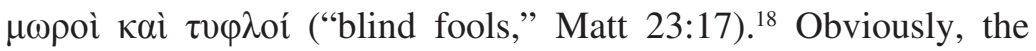
different sources do not necessarily have to align within the NT. However, Robert Horton Gundry has noted that they are also not truly contradictory, since the term is used in several places in Matthew specifically to signify "those who do not belong to the kingdom of heaven." 19

In light of these other uses of the insult "fool," Gundry suggests we should read it as "expressing a negative judgment, private and premature, against a brother's membership in the kingdom." 20

16. For a survey see footnotes in Guelich, "Mt. 5:22," 39-52; Betz, Sermon on the Mount, 222 and n181; and Davies, Critical and Exegetical Commentary, $515-16$.

17. Jonathan M. Watt, "Some Implications of Bilingualism for New Testament Exegesis," in The Language of the New Testament: Context, History, and Development (eds. Stanley E. Porter and Andrew W. Pitts ; Leiden : Brill, 2013), 9-27. The quotation appears on p. 27.

18. And a similar use of a different root by Paul, when he rails against the

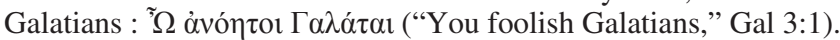

19. Robert Horton Gundry, Matthew : A Commentary on His Handbook for a Mixed Church Under Persecution (Grand Rapids, Mich. : Wm. B. Eerdmans, 1994), 84-85. See Matt 7:26;23:17; $25: 2,3,8$. In another attempt to reconcile the two Matthean passages Katell Berthelot has suggested to me that Matt 23:17 is a section that clearly denounces a lack of intelligence concerning religious or spiritual issues (blindness), in a context of "inverted beatitude". There, says Berthelot, Jesus is not insulting his opponents out of anger (thus he is not doing what he denounces in 5:22), but predicting their unhappy fate, which is a consequence of a real spiritual flaw (in the redactor's perspective), and in the redactor's perspective, Jesus is not telling this out of anger, and therefore not doing what he denounces in Matt 5.

20. Gundry, Matthew, 85 . 
Taking this stance even further, Garlington proposes that " $f o o l$ ' is a shot aimed not at one's IQ but at one's salvific condition or state of soul. That is to say, the fool has no part in the (eschatological) kingdom of God." ${ }^{21}$ It is not, therefore, in contradiction with the depiction of Jesus' own use of this slur against the Pharisees because he is accurately pointing out the Pharisees' status as unbelievers. To call a brother or a sister a "fool" meant, according to Garlington, condemning him unjustly. Such a condemnation deserves, as stated by Jesus, a trial for murder. Even if one does not fully accept this last suggestion, it seems, therefore, that the use of the insult "fool" carried particular content when used in this environment. It is an insult meant to signal a certain type of opponent understood in a specific theological context.

But even if we do not turn to the theological ramification of this insult, recent scholarship has urged us to consider the more general function of such insults in the culture of the ancient world. Slurs such as "fool" should not be seen as mere harmless words ${ }^{22}$ but rather as "genuine social weapons intended to cause serious injury." ${ }^{23}$ When uttered by influential persons, the use of such negative labelling can cause real damage. And as such, later rabbinic law, for example, deems it worthy of punishment in courts, ${ }^{24}$ and one Talmudic saying even compares public insults to spilling blood. ${ }^{25}$ Even without casting doubt on their eschatological future, it defines the one being insulted as an outsider to the social

21. Don Garlington, "'You Fool!': Matthew 5:22," Bulletin for Biblical Research 20 (2010) : 61-84. The quotation appears on p. 68.

22. See for example Luz, Matthew, 235: "[Р $\alpha \kappa \alpha$ á] a frequently used, quite harmless, condescending expression that meant something like 'feather brain'... 'Fool' (M $\omega \rho \varepsilon$ ) is a common Greek word of abuse with a nuance of disrespect, but it too has little importance." And see n16 there for Chrysostom and Basil on this word.

23. Jerome H. Neyrey, Honor and Shame in the Gospel of Matthew (Louisville, Ky. : Westminster John Knox, 1998), 192.

24. See for example, m. B. Qam. 8:1 and m. Ketub. 3:7. Basser, Gospel of Matthew, 141-42.

25. B. Baba Meșia 58b. See for example Luz, Matthew, 237, where he concludes that "Jesus' demand is nothing new in the framework of contemporary Jewish parenesis $[=$ Greek term for sections of the epistles dealing with moral exhortation]. [...I] $\mathrm{n}$ its content the first antithesis is not at all original. Jesus simply formulates it more sharply and in a more attention grabbing way by couching his admonition in the form of a legal sentence." Luz, Matthew, 237-38, views Jesus' unique contribution in creating contrasts between parenesis with the existing legal system. 
order and as "permanently deviant."26 This is the context in which, according to Jesus, using such an insult deserves punishment from the Sanhedrin. In the words of Jerome Neyrey, "In an honor-shame culture, there is no such thing as a harmless insult." 27

In this paper, I wish to claim that these insults in the Sermon on the Mount should be read in light of a specific context and not just as general slurs, which explains Jesus' severe reaction to their use. I will draw on the context of Matthew 5, other passages in the New Testament, contemporary sources from Qumran, and later rabbinic sources to offer a new understanding of this passage from Matthew. My new interpretation will draw attention to the use of these insults as part of a conversation about the correct interpretation of Scriptural law. I will show that several contemporary groups were each claiming to be the legitimate interpreters of the law and invoking these insults against the others to mark them as false interpreters. According to this reading of Matthew 5, Jesus is stressing the severe ramifications of using such slurs lightly.

\section{“FOOL" AND DORESHE HAHALAQOT}

As noted by Watt, in Matthew 23, Jesus is using the slur "fool" as synonymous with the terms "hypocrite" and "blind," or these terms are at least close in their "paradigmatic" relationships: ${ }^{28}$

But woe to you, scribes and Pharisees, hypocrites... Woe to you, blind guides... You blind fools...

David Garland surveys the use of "hypocrisy" in the New Testament, ${ }^{29}$ claiming that it involves much more than "pretending to have moral or religious beliefs which one does not actually possess," or "performing for the sake of an audience." ${ }^{30}$ Rather,

26. See Bruce J. Malina and Jerome H. Neyrey, Calling Jesus Names: The Social Value of Labels in Matthew (Sonoma, Calif. : Polebridge Press, 1988), 35-42, "Introduction to Labelling Theory."

27. Neyrey, Honor and Shame, 193.

28. Watt, "Some Implications of Bilingualism," 71.

29. David E. Garland, The Intention of Matthew 23 (Leiden: Brill, 1979), $91-123$.

30. Garland, Intention, 115-16. 
according to him, the term can be shown to convey a sense of false teaching (such as in Gal 2:13), a false exposition of the law (as in Luke 13:10-17, the healing of the woman on the Sabbath, and Matt 15:1-7, purity laws), and even more specifically in the sense of legalistic teaching (1 Tim 4:1-3): ${ }^{31}$

Now the Spirit expressly says that in later times some will renounce the faith by paying attention to deceitful spirits and teachings of

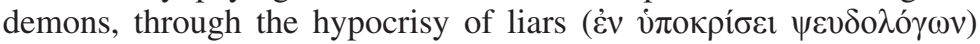
whose consciences are seared with a hot iron. They forbid marriage and demand abstinence from foods, which God created to be received with thanksgiving by those who believe and know the truth.

Hypocrisy, as Garland reads these sources, cannot be understood in the sense of false performance, but must be read in reference to false teaching of the law. In this sense, "hypocrites," used when describing persons, is targeted against those with the responsibility and authority to convey these teachings. It is, says Garland:

a radical subversion of God's will manifested especially in the false interpretation of the scribes and Pharisees. The scribes and Pharisees confidently (whether knowingly or unknowingly) endorse man-made traditions as God's will, when in fact these obstruct the intention of God's Law. ${ }^{32}$

Whether or not one accepts Garland's reading in all of his sources (for example, a later dating of 1 Timothy would make the case for the centrality of the law much weaker), ${ }^{33} \mathrm{I}$ am interested in the connection he makes between this possible sense of the term hypocrite, and a close Qumranic term. Garland connects the double meanings of the word "hypocrite" (both the common notion of one who professes beliefs that he doesn't actually practice and the more specific NT sense of one who spreads false teachings) with the group referred to in the Qumranic texts as דורשי חלקות (doreshe halaqot). In these Qumranic sectarian texts the term doreshe halaqot is generally agreed to refer to the Pharisees, ${ }^{34}$ (one of the sect's opposing groups, which the rabbis later saw as their predecessors), but scholars have been conflicted on the meaning of the epithet. The common translation, "seekers of smooth things," is

31. Garland, Intention, 112-13.

32. Garland, Intention, 116.

33. I am grateful to Tobias Nicklas for discussing this with me.

34. Garland, Intention, 104-112. 
based on Isaiah 30:10:דברו לנו חלקות, "speak to us smooth things." According to this reading, חלקות (halaqot) are smooth things which sound correct but are in fact false. However, the exact translation of the complete term, דורשי חלקות (doreshe halaqot) is debated. The negative sense of the epithet has been understood to refer to the Pharisees' hypocrisy and their practice of studying the Torah in slippery ways. ${ }^{35}$ Others read (halaqot) as referring not to the Pharisees' ethical behavior but to the accusation that their interpretations of the Jewish Law, the Torah, lead to lenient legal positions. ${ }^{36}$ Hoenig suggests that we view this term as a word play on הלכות (halakhot, rabbinic law). ${ }^{37}$

Indeed, some scholars have rejected the more common translation of this Qumranic term as "seekers of smooth things," in the sense of flattery, since it is connected contextually with what Garland calls "false counsel and interpretation which misunderstands God's law and misleads the people of God." ${ }^{38}$ For example, the term appears in the desert scrolls in conjunction with the epithets "seers of deceit" and "interpreters of falsehood" who "bartered God's law" (להמיר תורתכה) for "flattering words" (לחלקות [be-halaqot]). specific charge is intended not only as a critique of their ethical character but also of their methods of interpreting Scripture. Meyer therefore suggests translating דורשי חלקות (doreshe halaqot) as "those who give false interpretations of Scripture." 40

According to this convincing observation, Qumran's doreshe halaqot and the New Testament's "hypocrites" carry similar meanings when used as slurs against the Pharisees. Given the parallel uses of the terms in Matthew, the adjectives "fool" and "blind" should also be connected to these slurs, which all signal

35. David Flusser, "Pharisees, Sadducees and Essenes in Pesher Nahum," in Studies in Jewish History and the Hebrew Language : Gedaliah Alon Memorial Volume (Hebrew ; ed. D. Dormann, S. Safrai, and M. Stern ; Tel Aviv : Hakibbutz Hame'uhad, 1970), 133-68.

36. Godfrey R. Driver, The Judean Scrolls: The Problem and a Solution (Oxford : Blackwell, 1965), 94.

37. Sidney B. Hoenig, "Dorshe Halakot in Pesher Nahum," Journal of Biblical Literature 83 (1964) : 119-38.

38. Garland, Intention, 109.

39. 1QH 4:9-10. See Garland, Intention, 108.

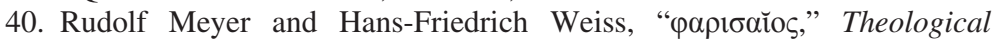
Dictionary of the New Testament (ed. G. Kittel and G. Friedrich; trans. G.W. Bromiley ; 10 vols. ; Grand Rapids, Mich. : Wm. B. Eerdmans, 1964-1976), 9:30. 
a shared semantic field, describing the Pharisees. They are all connected to the Pharisees' false ways of interpreting Scriptural law. Garlington even takes this conclusion one step further, suggesting that the terms "fool" and "hypocrite" should be viewed as semantically equivalent to "heretic" and "unbeliever."

\section{DORESHE HALAQOT AND REQ}

I want to turn to a suggestion by Nahum M. Bronznick for the etymology of doreshe halaqot. ${ }^{42}$ Bronznick suggests that the חלק (halaq) should be understood in light of other rabbinic uses of this root in the sense of "empty" (req), or "without content," such as in the phrase נייר חלק (niyyar halaq), "an empty paper" (b. Shab. 78b). According to this reading, the Qumranic epithet doreshe halaqot is a derogatory nickname which turns one of the Pharisees' primary claims on its head: they claim to have interpreted Scripture and filled it with meaningful content, but they are actually "the interpreters of empty things" or "the creators of empty Scriptural interpretations."

While Bronznick himself does not expand on this issue, I wish to examine this rabbinic self-perception in passages interpreting Deuteronomy 32:47. This verse appears at the end of the Deuteronomist hymn "Listen, you heavens," in a concluding paragraph by Moses, and employs the word "empty":

When Moses finished reciting all these words to all Israel, he said to them, "Take to heart all the words I have solemnly declared to you this day, so that you may command your children to obey carefully all the words of this law. They are not just idle words for you (lit: "an empty matter (ר req) for you") —-they are your life. By them you will live long in the land you are crossing the Jordan to possess."

In rabbinic interpretation of these verses, the word 7 req, "empty," and its negation, "not empty," stand at the heart of rabbinic descriptions of their own hermeneutical project. At this point, I want to stress that I am aware of the much discussed methodological problem of using later sources-rabbinic literature of the first

41. Garlington, "'You fool,"” 83.

42. Nahum M. Bronznick, "The Meaning of Doreshe Halaqot" (Hebrew), Tarbiz 60 (1991) : 653-57. 
through fifth centuries $\mathrm{CE}$ - in order to try and reconstruct a Second Temple conversation. However, scholarship in recent decades, since the publication of the Dead Sea Scrolls, has amply shown the light that can be shed from the later sources on the earlier ones through careful analysis. ${ }^{43}$ In this case, I see the rabbinic sources as part of a wider conversation, whose other participants can be recognized in the earlier, Second Temple and New Testament sources.

\section{"IT IS NOT AN EMPTY MATTER FOR YOU" IN RABBINIC LITERATURE}

I start with the Palestinian Talmud $(=y$. redacted around the end of the fourth century) Pe'ah 1:1 (15b-d) ${ }^{44}$ in which R. Mana interprets the words of the verse as follows:

R. Mana said, "'It is not an empty matter (davar req) for you.' If it is empty (req), it is 'for you,' since you do not exert yourselves for it. 'For it is your life.' When is it your life? Anytime you are exerting yourselves for it." [...] R. Mana learned (lit. heard) all [of the above] from this verse: "It is not an empty matter for you," this is the study of Torah; "for it is your life," this is the commandment to respect one's father and mother; "and through this you will lengthen your days," this is charity (lit. "acts of kindness"); "in the land," this is making peace between people.

The context of this specific passage is a discussion of oral traditions pertaining to the interpretation of the Law (Torah) forgotten by later generations and restored through the dedication of the rabbis. These

43. There are many possible references for this sort of research, but see, for example, Lutz Doering, "Parallels without 'Parallelomania': Methodological Reflections on Comparative Analysis of Halakhah in the Dead Sea Scrolls," in Rabbinic Perspectives: Rabbinic Literature and the Dead Sea Scrolls, Proceedings of the Eighth International Symposium of the Orion Center for the Study of the Dead Sea Scrolls and Associated Literature, 7-9 January, 2003 (ed. Steven D. Fraade, Aharon Shemesh, and Ruth A. Clements ; STDJ 62 ; Leiden : Brill, 2006), 13-42, and Steven D. Fraade, "Shifting from Priestly to Non-Priestly Legal Authority: A Comparison of the Damascus Document and the Midrash Sifra," Dead Sea Discoveries 6 (1999) : 109-25 ; idem, "The Temple as a Marker of Jewish Identity Before and After $70 \mathrm{CE}$ : The Role of the Holy Vessels in Rabbinic Memory and Imagination," in Jewish Identities in Antiquity : Studies in Memory of Menahem Stern (ed. Lee I. Levine and Daniel R. Schwartz ; Tübingen : Mohr Siebeck, 2009), 237-65.

44. Bronznick, "Meaning," 655 , refers very briefly to the first part of this quote and not to the other sources discussed here. 
laws are equated to those laws that were given to Moses at Sinai. In this passage, partially quoted in several contexts in the Palestinian Talmud, ${ }^{45}$ R. Mana presents an equation: not empty = Torah study. The hard work of interpretation is said to be equal to life itself, and it is made empty by the lack of serious study. The act of painstaking study makes it "not empty" and full of life-worthy meaning.

An earlier work, the legal midrash Sifre Deuteronomy (redacted around the $3^{\text {rd }}$ century CE, but containing earlier material going back to the Second Temple period), explains in the aggadic part the tricky task of retaining one's study: it is hard to acquire but easy to lose. In this context the midrash asserts: "It is not an empty matter for you': what you say is empty_-'it is your life' (\$48)." ${ }^{\prime 4}$ We see here again the identification of the negation of emptiness with the study of Torah. In another passage (Sifre Deuteronomy 335) the study of Torah is again opposed to emptiness:

"It is not an empty matter (davar req) for you." There is nothing empty in the Torah, which, when interpreted, will not earn you a reward in this world, with the principle remaining intact for the world to come.

The Torah is "not empty" when studied, earning the learner both profit in this world and reward in the next world. In yet another passage in the same Sifre portion (48) this verse is cited to stress that one should not study difficult Scriptural verses and ignore the easy ones, because "what you say is empty-it is your very life." Torah is never "empty."

In a later, Amoraic midrash, Genesis Rabbah 1:14 (redacted around the fifth century CE in Palestine), R. Akiva, the master of rabbinic scriptural interpretation, is asked a question about a verse in Genesis by R. Ishmael, in reference to his former studies with Nahum of Gimzo, who formulated rabbinic hermeneutical principles in the study of Scripture: ${ }^{47}$

45. The first part has several parallels : y. Shev. 1:5 (33b); y. Shab. 1:4 (3d) ; y. Sukkah 4:1 (54b) ; y. Ketub. 8:8 (32c).

46. For the English translations here, I used Sifre : A Tannaitic Commentary on the Book of Deuteronomy (trans. and introd. Reuven Hammer; New Haven, Conn. : Yale University Press, 1986), but corrected it to fit MS versions and local vocabulary needs. 47. The literary structure of this passage appears in three different places in Gen. Rab., on three different verses : Gen $1: 14 ; 22: 2$; and $53: 15$. In all of these instances, R. Akiva is asked about a verse in connection with the use of Nahum of Gimzo's hermeneutical rules. He answers the question but is answered by 
R. Ishmael asked R. Akiva: "Since you have studied twenty-two years under Nahum of Gimzo, [who formulated the principle that] $a k h$ (save that) and raq (except) are limitations, while et and gam (also) are extensions, what of the et written here ["In the beginning created God the (et) heaven and the (et) earth']?" Said he to him: "If it stated, 'In the beginning created God heaven and earth,' we might have maintained that heaven and earth, too, are divine powers [=without the et signaling the accusative, the heaven and earth could be read as nominatives in apposition to the word "God"]. He [=R. Ishmael] said to him: " It is not an empty matter from you,' and if it is empty, it is 'from you', because you are unable to interpret it [rightly]. Rather, 'the (et) heavens' is to include the sun and moon, the stars and planets; 'the (et) earth' is to include trees, herbage, and the Garden of Eden."

R. Ishmael's words are similar to what we find in the abovequoted passage from the Palestinian Talmud, but it pushes the point even further: the emptiness is not only dependent on the amount of effort invested in the study of the Torah, but also on the level of proficiency reached. In the context of the use of elaborate rabbinic hermeneutical tools in the study of Scripture, and as an opposition to R. Akiva, R. Ishmael says: the use of correct rules is what gives Scripture its meaning and removes it from emptiness.

In this case, the rabbinic interpretation explains the need for the accusative marker (et), without which the verse might be understood in a theologically problematic fashion. If we look closely at the argument itself and compare it to two parallel narratives in this midrash, Genesis Rabbah, we can deepen our understanding of the polemical context of the term "empty." In these parallels, we find similar literary constructions. In Genesis Rabbah 53:15, R. Ishmael asks R. Akiva to explain the preposition in Genesis 21:20: "God was with (et) the boy [=Ishmael]." R. Akiva explains that without the preposition et (with), the sentence might convey that God was the boy. R. Ishmael quotes Deuteronomy 32:47 and then supplies a different explanation according to which the preposition is used to add to the boy his family and property. In the third passage, Genesis Rabbah 22:2, R. Ishmael asks R. Akiva about the verse describing the birth of Cain (Gen 4:1):

R. Ishmael asked R. Akiva: "Since you have served Nahum of Gimzo for twenty-two years, [and he taught that] every et and gam is an extension and every $a k h$ and $r a q$ is a limitation, tell me what is

R. Ishmael, who quotes Deut $32: 47$ to accuse him of misunderstanding the verses, and then goes on to supply a different interpretation. 
the purpose of the $e t$ written here [='I have gotten a man with (et) the Lord']?" He said to him: "If it said, 'I have gotten a man the Lord,' it would have been difficult [to interpret, since the lack of the preposition makes it look as if the man is God, and that she has given birth to the Lord himself]; hence 'et [=with the help of] the Lord' is required." $\mathrm{He}$ said to him: "“'It is not an empty matter from you,' and if it is empty, it is 'from you,' because you are unable to interpret it [rightly]. Rather, 'with (et) the Lord' [teaches this]: in the past, Adam was created from earth, and Eve was created from Adam; henceforth, it shall be, 'In our image, after our likeness' (Gen 1:26) - neither man without woman nor woman without man, nor both of them without the shekhinah.

Here, as well, the absence of the preposition might have created a sentence with problematic theological ramifications. In all three cases, R. Ishmael quotes Deuteronomy 32:47 to stress the importance of a correct interpretation of these verses, pace R. Akiva. In all three passages, the rabbinic interpretation explains the need for the et proposition, without which God could have been understood either as having himself been created, as being identified with the boy, or as being born to a woman. In this last midrash, I think we can detect a clear anti-Christian polemic, since the ending states that the creation of humans now requires all three elements-shekhinah, woman, and man ("nor woman without man"). This seems to me to be a clear rejection of the virgin birth of Jesus: there are no exceptions-since the creation of the first man and woman, all humans, beginning with Cain, must have a father.

One could make the case that similar polemics underlie the other two midrashim cited above. In one, we see an attempt to determine exactly which elements were included in creation, similar to the Christian occupation with logos, most famously in the opening verse of the gospel of John. In the case of Genesis 21:20, perhaps the intention is to counter contemporary Christian readings that see another boy in this story, Isaac, as a figure of Christ.

I want to stress that I am not certain there is indeed a clear antiChristian polemical background to all three stories. But one can disregard these last passages and see that the bottom line is still valid: the use of Deuteronomy 32:47 ("It is not an empty matter from you") asserts that correct rabbinic interpretation is what makes the Torah full and prevents scriptural misunderstandings.

To sum up this part of my argument: we see here a clear context in rabbinic literature in which the word (req), "empty," is tied 
to the rabbinic hermeneutical study of the Torah. The rabbinic passages assert that their methods are what render the Torah full rather than empty.

\section{"Our Full Torah"}

It is within this semantic context that the Qumran writers ridicule the Pharisees by calling them דורשי חלקות, "ones who study empty things." Bronznick identifies a possible counter-argument to this Second Temple slur in a famous passage in which R. Yohanan b. Zakkai argues with the Sadducees/Boethusians about the exact date for the beginning of the count of the Omer between Passover and Pentecost. ${ }^{48}$ When answering their claims, R. Yohanan says: Fool! Should not", שוטה. לא תהא תורה שלימה שלנו כשיחה בטילה שלכם our full Torah be [as convincing] as your idle/empty talk?"49

While the passage is found in later sources, scholars believe it might still reflect earlier, Second Temple arguments. ${ }^{50}$ For our purposes, notice here Bronznick's recognition of the use of the term "full Torah" as a possible negative attribute to an "empty Torah," and my own focus on the use of the slur "fool." The rabbinical figure in these stories is asserting the "fullness" of his Torah as well as the "foolishness" of his opponents" on matters of legal exegesis.

\section{"FOOL" IN RABBINIC LITERATURE}

The שטיא (shatya; Aramaic)/שוטה (shote; Hebrew), "fool," appears often as a legal category in rabbinic literature, frequently

48. The בייתוסין, "Boethusians," are a Second Temple group mentioned only in rabbinic literature and interchangeable in some sources with the Sadducees. On the possible identification of this group, see Raymond Harari, Rabbinic Perceptions of the Boethusians (Ph.D. diss., New York University, 1995).

49. This passage appears in $b$. Menah. $65 \mathrm{~b}$, and the term itself appears in another context in $b$. B. Bat. 116a, but both are also a part of the Megillat Ta'anit and its scholion. On this, see Vered Noam, Megillat Ta'anit : Versions, Interpretations, History (Jerusalem : Yad Yitzhak Ben-Zvi, 2003), 135-40 and 174-79. While bețelah on its own doesn't necessarily mean "empty," the opposition to "full" makes it clear that this is the case here.

50. Ibid. 
coupled with the categories of the hearing-impaired (heresh) and minors (qatan). In a few instances, however, it seems to carry specific implications as a derogatory term. The latter use of "fool" as a slur is not very common, appearing in relation to a handful of people who are criticized for foolish behavior (Babylonian Talmud [=b.] 'Avod. Zar. 51a) or foolish sayings (b. Hul. 85b; b. Nid. 52b). Most notably, it is used against specific groups, such as the Sadducees, in the source mentioned above, or Galileans ( $b$. 'Eruv. 53b). Jesus is also called a fool (b. Shab. 104b).

The term also appears in a group of stories in the Babylonian Talmud where a rabbinic figure (Rabbi, Beruriah, R. Abbahu) argues with a $\min$ (lit. "a heretic") over Scriptural exegesis. ${ }^{51}$ In response to a defiant question on matters of Scripture, the rabbinic figure exclaims: שטיא שפיל לספיא דקרא, "Fool! Read on to the end of the verse [for a correct understanding of its meaning]." Scholars have recently tried to demonstrate the Jewish-Christian polemical background for these stories. ${ }^{52}$ If I am correct in my readings, we see that the use of the slur "fool" has a clear connection to fierce Scriptural arguments in rabbinic literature as well.

I chose to focus here on the word שוטה (shote), since scholars such as Guelich have marked it as the Hebrew/Aramaic lexical equivalent of $\mu \omega \rho \varepsilon$ (mōre) in Matthew, and it could well have been the term translated by the Greek..$^{53}$ However, the word used by Matthew, raka, has an equivalent in rabbinic literature as well. It is used in several sources (such as Mekhilta deRabbi Ishmael, Bahodesh 5; b. Ta'an. 20a; b. Ber. 22a; b. Git. 58a; b. B. Qam. $50 \mathrm{~b})$ as a general insult without the added context one finds with the word shatya or shote.

In a few instances, however, even this term is used in contexts that suggest added hostility: in the Babylonian Talmud, Sanhedrin 100a, a student is doubtful of a rabbinic tradition about God's future fantastic deeds. After the student has a vision that confirms

51. B. Hul. 87a ; b. Ber. 10a; b. 'Eruv. 101a; b. Sukkah 52b.

52. Elitzur and Michal Bar-Asher Siegal, "'Rejoice, O Barren One Who Bore No Child' : Beruria and the Jewish-Christian Conversation in the Babylonian Talmud," in The Faces of Torah: Studies in the Texts and Contexts of Ancient Judaism in Honor of Steven Fraade, Christine Hayes and Tzvi Novick, Michal BarAsher Siegal (eds.), Supplements to the Journal of Ancient Judaism (forthcoming June 2017).

53. Guelich, "Mt 5:22," 41-42. 
the truth of the tradition, he tells R. Yohanan about his vision and is criticized for only believing after seeing. The student is called "a fool," ריקא (reqa) and "one who mocks rabbinic teachings" and is promptly turned into a pile of bones. Interestingly, the accusation of "mocking rabbinic teachings" occurs only one other time in rabbinic literature, in reference to Jesus. In $b$. Gittin 57a, Jesus is summoned in a séance and tells of his fate in hell, sitting in boiling excrement. ${ }^{54}$ The reason for this punishment is the rabbinic dictum that "whoever mocks the teaching of the sages is liable to sit in boiling excrement." 55 I will point out once more that Jesus, in another rabbinic passage, is also called "a fool" (shote) ${ }^{56}$ The combination of these elements suggests again that these insults share a specific polemical context, arguing over rabbinic authority.

Another passage in which the insult reqa appears is $b$. Ketubot $112 \mathrm{a}$, where $\mathrm{R}$. Zera is trying to cross a river using a rope rather than a ferry boat. He is criticized by a min, "heretic," who associates his haste with that of the Israelites when they accepted the Torah at Sinai. R. Zera answers by calling the min "a fool," ריקא (reqa). Again, the context is very clearly polemical. However, as opposed to the insult שוטה/שטיא (shote/shatya), the insult reqa does not seem to be used specifically in reference to scriptural arguments. Therefore, I choose to read Matthew's raka in relation to the rabbinic shatya and the accusation of being "empty" in relation to the sources discussed above.

In summarizing the information gathered thus far, we see that in Second Temple sources and continuing into rabbinic literature, there existed several words within a certain semantic field intimating an accusation concerning the proper understanding of Torah laws. Central to these terms is the use of the word "empty," חלק (req), or its equivalaq), and its opposite, the "not empty" but rather full understanding of Scripture. Qumranic literature claims that the Pharisees' interpretations are empty, while passages within rabbinic literature strongly maintain that rabbinic hermeneutical methods in the study of Scripture are what make

54. On this Talmudic tradition see Peter Schäfer, Jesus in the Talmud (Princeton, N.J. : Princeton University Press, 2007), 82-94.

55. In Jesus' case the verb used is מלעיג, while in the story of R. Yohanan's student it is מלגלג, but the words are synonymous.

56. B. Shab. 104b. See above p.10. 
the Torah full and not empty. Alongside the use of the word req, "empty," we also find the use of the insult "fool" (shatyalshote).

\section{MATTHEW 5:22 AND THE MISINTERPRETATION OF THE LAW}

Going back to the passage with which we started our discussion we might be able to better understand Jesus' words in Matthew's Sermon on the Mount:

You have heard that it was said to the men of old, "You shall not murder"; and "whoever murders shall be liable to judgment." But I say to you, everyone who is angry with his brother or sister is liable to judgment. Whoever says to his brother or sister, "Raka" (P $\alpha \kappa \alpha ́)$,

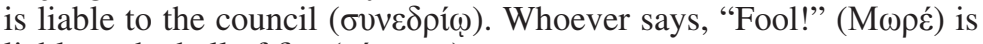
liable to the hell of fire $(\gamma \varepsilon \dot{\varepsilon} \varepsilon v \nu \alpha v)$.

I wish to suggest that Jesus' proscription here is referring neither to harmless insults nor only to a general term for people who do not belong to the kingdom of heaven. I think these specific

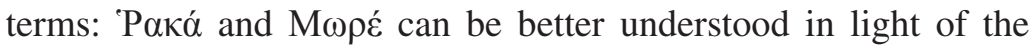
connotation of the words (req), "empty," and "fool" in their Second Temple and rabbinic uses. When Jesus says that one who unjustly calls a brother or a sister raka, "empty one," or "fool" should suffer severe consequences, he specifically refers to an insult that suggests a misunderstanding of Torah laws.

The teaching of Jesus in this textual unit $(5: 21-26)$ is about anger and about brotherly dispute. Jesus's reference to calling someone raka or möre can be understood as an example of the kind of fault or sin one is at risk of committing if one succumbs to anger. However, Jesus emphasizes the particular insults the angry person should not use when referring to his brother or sister. And they should, as seen above, be understood as connected to hermeneutical disputes. ${ }^{57}$

This sentence should thus be read: "Whoever says to his brother or sister [a fellow, not a deserving opponent], 'Raqa,' [accusing his brother of false and empty interpretations of Scripture] is liable to the council. Whoever says, 'Fool!' [insulting his brother as one insults polemical opponents] is liable to the hell of fire." We now know the context within which the Matthean Jesus is speaking:

57. I am grateful to Katell Berthelot for her help with phrasing this point. 
he himself uses similar derogatory terms; the Qumran writings call the Pharisees these names; and rabbinic literature preserves responses against such claims.

If my suggestion is correct, this teaching of Jesus aligns nicely with Jesus' teaching in 5:17-20. There, he specifies the way he accomplishes, and thus understands and interprets, the Law: "Do not think that I have come to abolish the Law or the Prophets... I tell you that unless your righteousness surpasses that of the Pharisees and the teachers of the law, you will certainly not enter the kingdom of heaven." In line with the moral emphasis of these words, the harsh tone and severe punishment put forward by Jesus are appropriate. Consistent with the rest of the Sermon on the Mount, Jesus turns to a moral proscription rather than a legalistic one: it is not just the misinterpretation of Scripture that is the cause for such punishments, but even the false accusation that another misinterprets it. You say that we should go to the Sanhedrin and gehenna when we misinterpret the law? I say that the flinging of such insults deserves the same severe punishment. Easy recourse to anger, slurs, and insults deserves just as much punishment as the original crimes you insultingly accuse your brother or sister of having committed. In this context, insults are genuine social weapons and cause real injury, especially where these specific insults are understood as denoting a very specific theological transgression.

In pushing the point further, one might even consider this verse as part of the anti-Qumranic polemics shown in other parts of the Sermon on the Mount. Kurt Schubert identifies those who say: "Love your neighbor and hate your enemy" in Matt 5:43 as Essenes. He bases this suggestion on the similarity to passages such as 1QS I 4: "Love everyone whom God has elected and hate everyone whom he has rejected." 58 Thus, similarly, in our Matthew verses on anger and insults Jesus could be polemicizing specifically against attitudes involving such insults, found in other Jewish groups, given as examples of reprehensible angry

58. K. Schubert, "The Sermon on the Mount and the Qumran Texts," in The Scrolls and the New Testament (ed. K. Stendahl ; London : SCM Press, 1958), 118-28. He also suggests an anti-Essene background to the mention of "the poor" and the prophets in Matt 5:12. And see also George J. Brooke, The Dead Sea Scrolls and the New Testament (Minneapolis : Fortress Press, 2005), 231-32. 
behavior. ${ }^{59} \mathrm{He}$ could be referring to the practices of the Qumranites alone, or even to both Qumran and Pharisees groups (as they are known from later rabbinic sources). But in any case, these specific insults, known from contemporary groups, and aimed at one's understanding of Scripture, are deemed worthy of hell and are singled out to the listeners of Jesus' message.

In conclusion, the use of sources outside the New Testament, from the writings of Qumran to those of the rabbis, help to clarify the semantic and theological field in which Matthew 5:22 should be understood. The correct interpretation of the law is depicted as having stood at the center of arguments between different groups at the time of Jesus, and probably later as well. The insults "empty" and "fool" can be seen as connected to this polemical environment, and it is within this setting that the Sermon on the Mount can be understood.

bsmichal@bgu.ac.il

59. I owe this suggestion to Katell Berthelot and am grateful for her help with this point. 